\title{
Marketing Ethics and Relationship Marketing - An Empirical Study that Measure the Effect of Ethics Practices Application on Maintaining Relationships with Customers
}

\author{
Muhammad Alshurideh ${ }^{1}$, B. H. Al Kurdi ${ }^{2}$, Anu Vij ${ }^{3}$, Zaid Obeidat ${ }^{1}$, Abdallah Naser ${ }^{4}$ \\ ${ }^{1}$ Marketing Department, The School of Business, The University of Jordan, Amman, Jordan \\ ${ }^{2}$ Lecturer, Marketing, Amman, Jordan \\ ${ }^{3}$ School of Business Administration, Al Dar University College, Dubai, United Arab Emirates \\ ${ }^{4} \mathrm{PhD}$ Student, University College London \\ Correspondence: Muhammad Alshurideh, The School of Business, The University of Jordan, Amman, Jordan. \\ E-mail: m.alshurideh@ju.edu.jo
}

Received: August 19, 2015

Accepted: September 16, 2015

Online Published: July 25, 2016

doi:10.5539/ibr.v9n9p78

URL: http://dx.doi.org/10.5539/ibr.v9n9p78

\begin{abstract}
The purpose of this study is to measure the effect of ethics embedded practices on maintaining long-term relationships with customers. Based on an extensive literature review, four elements of marketing ethics, namely, honesty, autonomy, privacy and transparency were identified and examined by utilizing a sample of 360 participants. Adopting a quantitative approach, the study conducted on telecommunication sector subscribers revealed that the elements of marketing ethics affected an organization's ability of maintaining long-term relationships with customers and had a strong influence on feedback, transparency and privacy. The results also showed the crucial role of generating feedback from customers for creating and maintaining long-term relationships. The results will enable marketers to not only analyze the importance of adopting ethical practices in their strategies but also the relative relevance of these practices as perceived by customers.
\end{abstract}

Keywords: marketing ethics, feedback, relationship marketing, honesty, autonomy, privacy and transparency

\section{Introduction}

Contemporary business trends focus on including ethical practices in business while ensuring the durability of an organization's business with their customers. The rapidly-spreading practice of dishonest promotion and marketing acts and its harmful effect on an organization's reputation and success, has forced organizations to change their business practices to be more aligned with ethical practices. Buttle (1996) indicates that relationship marketing with a focus on seeking long-term relationships with customers is the right solution to grow current economies and might determine the future of marketing practices. Increasingly, organizations have started taking an interest in ethical practices owing to the contribution of ethical practices in enhancing the reputation of organizations and their employees in the minds of customers.

Consequently, for any business there is a crucial need for an ethical climate that sharpens their behavior and guides their processes. Business goals these days have shifted from being more focused on acquiring new customers to being more oriented towards customer-retention practices and prolonging the duration of the organization's customer-business relationship (Winer, 2001). However, the success of applying those trends is highly-dependable on the organizations' ability to build relationships and managing them effectively (Hawkins, 2011). For example, Cramton and Dees (1993) found that it is too costly to compensate the negative consequences of unethical behavior for the aggrieved party. Therefore, organizations must apply an ethical climate within their internal environment and also while dealing with customers and the external environment. Practicing ethics in marketing activities means applying standards of fairness and morality, to marketing decision-making behavior and practices in the organization (Majtán \& Dubcová, 2008).

This situation calls for effective and successful communication which is usually a two-way flow from the sender to the receiver and from the receiver to the sender, which must be clear and direct (Team Coordination Training Student Guide, 1998). Moreover, the effective communication must itself encourage customer feedback to benefit the two parties, the customer and the supplier. Ferrell (2007) stressed the importance of incorporating ethics in organizational communication with customers because of its importance and crucial role in maintaining long-term profitable 
relationships with customers. Generally, the role of ethics has a wide scope and can be applied to numerous subjects. Various dimensions of earlier ethical studies have been investigated on a number of areas including decision-making (Jamnik, 2011), international marketing (Borgerson \& Schroeder, 2005), banking (Abul Hassan, Chachi \& Abdul Latiff, 2008), branding (Fan, 2005), services (Abela \& Murphy, 2008), social marketing (Eagle, 2009), marketing management (Chonko \& Hunt, 1985) and even research (Hunt et al., 1984). However, despite the valuable insights previous research has provided, a need exists to conduct a study in a market in which limited research attention has been given, namely, the area of ethics and misbehavior of both firms and consumers (Obeidat, 2014). Thus, to test and clarify the dimensions of this relationship and to develop a clear perception about the factors that hinder and delay maintaining long-term business relationships with customers, this study was conducted in the telecommunication sector in Jordan. The purpose of this study was to assess the relationship between the ability of the organization to adopt ethical standards and maintaining long-term relationships with customers. In particular, the study aims to examine the relationship between the application of marketing ethics from a value-oriented framework and the organization's ability to maintain long-term relationships with its customers by examining the role of "feedback" in the relationship between the marketing ethics elements and maintaining long-term relationships with consumers.

In the current study, the variable of primary interest, which is the "dependent variable" is maintaining long-term relationships (relationship longevity) or the application of relationship marketing while the "independent variables" are the marketing ethics elements (honesty, autonomy, privacy and transparency) while the "mediating variable" is feedback. The study examines the application and perception of the marketing ethics elements among the three prominent telecommunications firms, namely. Zain, Umniah and Orange in Jordan.

The study contributes to the body of knowledge in two main ways; firstly, a conceptual model is proposed which incorporates feedback for the first time as a mediator between business ethics dimensions and relationship marketing. Secondly, this study was conducted in Jordan, thus, for the first time the ethical dimensions in Jordanian businesses were examined. This could provide valuable insights into the nature of the business ethics application in a new context and prove to be beneficial for the marketers in not only understanding the significance of ethical practices, but also about incorporating these practices in their upcoming marketing plans.

\section{Literature Review}

Marketing ethics is normally described as the field applied ethics that deals with the ethical principles behind the function and regulation of marketing (Majtán \& Dubcová, 2008). Thus, ethics can be applied to each element of the marketing mix, namely, product, price, distribution and promotion (Takala \& Uusitalo, 1996). Furthermore, Williams and Murphy (1990) indicated the need for principles and standards that guide managers and firms in making decisions and setting priorities in addition to stressing that ethics in marketing is an international trait that can be applied across different cultures. Normally, ethical problems arise in new marketing practices owing to the seller focusing on financial issues while ignoring ethical issues (Majtán \& Dubcová, 2008). Consequently, for the best practice and application of marketing ethics within organizations, there is a responsibility on the organizations to establish a code of ethics for its product-marketing practices. Ferrell (2007) indicates that marketing ethics is an organizational responsibility and is essential in maintaining long-term beneficial relationships and establishing mutual trust with customers. Takala and Uusitalo (1996) also stressed the importance of building and restructuring relationships between organizations and customers based on ethical communication. Similarly, Hunt and Parraga (1993) found that developing an ethical culture within any organization became a notable concern of organization managers and suggested the development of ethical training programs.

With regards to relationship marketing, Adcock et al. (2001) identify the four contemporary approaches of marketing as relationship marketing, business marketing, social marketing and branding. Additionally, Cateora et al. (2009) acknowledge that all new business trends are supporting the philosophy of long-term relationships in business. Furthermore, Abela and Murphy (2008) conclude that having a relationship with the customer is a strategy to persuade firms to resolve and reduce ethical tension and prevent the development of unethical behavior. Furthermore, Abela and Murphy (2008) assert that marketing ethics must be an essential practice which should be taken into consideration when organizations structure their marketing plans. Buttle (1996) also conclude that the main reason behind practicing relationship marketing and maintaining long-term relationships with customers is customer retention. Palmatier (2008) also indicate that the main advantage of adapting this relationship marketing is that it bypasses the conflict encountered by organizations that adopt traditional marketing models with their customers and show minimum interest in its relationship with customers. Additionally, Sheth and Parvatiyar (2002) found that relationship marketing represented a great shift in marketing practices to being more focused toward customer needs and wants, customer retention and commitment rather than the organization's market share. The uniqueness of the relationship-marketing approach is derived from the collaboration and cooperation that is incorporated between the supplier and the customer which add a meaningful value to their business relationship with each other. As a result, examining the influence of including ethical 
practices in marketing communications on the ability of a firm to maintain its relationship with consumers will provide valuable implications for marketing-strategy planning and customer handling.

Although a number of frameworks exist to ensure an understanding of the significance of ethics in marketing, the proposed framework in this study is inspired by the findings derived by Majtán and Dubcová (2008) who identified that various dimensions of ethics can be analyzed better on the basis of values a company violates. Majtán and Dubcová (2008) also identified and examined four elements, namely, autonomy, honesty, privacy and transparency. The current study has selected these four elements as the framework for the research.

\section{Marketing Ethics Elements}

This study aims at studying the effect employing a set of marketing ethics dimensions on maintaining suppliers' long-term relationships with customers. To achieve such aim, four dimensions of marketing ethics, namely, honesty, autonomy, privacy and transparency were researched theoretically and examined practically. This section explains such dimensions in more details.

\subsection{Autonomy and Relationship Longevity}

The ethical dimension of autonomy can be defined as an "Agreement to respect another's right to self-determine a course of action; support of independent decision making” (The American nurses association, 2011, pp.1). Wright and Rogers (2009) acknowledged that individuals by nature have the right to be autonomous and to direct his/her actions and to direct him/herself freely without any influence from others.

Polonsky et al. (2002) investigated that firms need to change their traditional way of dealing with their customers in a more productive and effective way, moving toward relationship marketing perspectives. Moreover, the rule of two parties in managing the mutual relationship that exists between the corporate and its customers should be emphasized, for example, the two parties must have influence independently in managing these relationships. When the company adopts the relationship-oriented approach, it must take into its considerations the welfare of the two parties because the relationship is a cooperative process. Reciprocity is an essential component of the relationship commitment which requires equivalent response to the other parties' actions. Williams and Murphy (1990) also found that one feature of persuasive promotion is to avoid invading the customer's autonomy. Moreover, Abela and Murphy (2008) also found that ethical issues are still a serious problem in today's marketing and business practices and have been since the 1950s. Consequently, this study also proposes that modern marketing theories should stress the importance of customer autonomy.

Khalili et al. (2009) also indicated that the most satisfactory level of the product or service can be delivered to the customer if clear and autonomous feedback is shared both explicitly and implicitly between the two parties. Hattie and Timperley (2007) concluded that feedback is one of the most effective tools that influence organizational achievement because it is a vital consequence of their overall performance. In addition, when feedback provides the organization with correct, honest and autonomous information with no interference from others, it will be more effective. Furthermore, from the customer's perspective, feedback decreases the gap between the actual performance of the organization and the expected performance. Moreover, Aztiria et al. (2008) found that the ideal work environment is the environment that promotes feedback and gathering data from the customers to be safely and proactively used without intervention from others.

The American communication company Avaya (2013) concluded that customer autonomy in business interactions has become a global trend that is desired by many organizations owing to its effect in maintaining effective relationships with customers.

As a result, for the study the following hypotheses were proposed for testing:

H1a: There is a statistically-significant effect for autonomy on maintaining long-term relationships with customers.

H1b: There is a statistically-significant effect for feedback on mediating the relationship between autonomy and maintaining long-term relationships with customers.

\subsection{Privacy and Relationship Longevity}

Efforts to provide a comprehensive definition for customer privacy, the second element in marketing ethics, has extended from the 1890s. Generally, privacy is "the right to be let alone" (Warren \& Brandeis, 1890). For the study, the definition of privacy is extended to include the right of the customer to have the only influence over his/her body, his/her home and other possessions in addition to the right to secure personal information and to protect his/her data (Canadian Marketing Association, 2004).

Privacy concerns may encompass many dimensions which include the use of individual personal information or possessions without permission, invading individual solitude, describe or characterize the individuals in a way that 
negatively presents them and sharing private information about individuals in public (Lanier \& Saini, 2008). Zwick and Dholakia (1999) also stressed that privacy is a crucial civil right. In addition to this, the new way of differentiation between different organizations from the customer's point of view will be based on the degree of privacy that the organization will offer its customers, and high standards of privacy will ensure high confidence in an organization's customers. Furthermore, Zwick and Dholakia (1999) specify that privacy is a norm-dependent concept. Lanier and Saini (2008) focused on the contribution of the advanced information technology and today's dynamic and changing environment and how it forces organizations to know more about their customers and to collect more and more information about them. Additionally, Wirtz and Lwin (2009) indicated that the relationship-marketing module stressed the importance of collecting customer information to encourage customers to share their information with other organizations and that organizations themselves must assure the customer and guarantee the privacy and the security of their customer information to build trust.

Bollen and Emes (2008) indicated that international companies in their websites encourage customers to give their feedback about the organization's products and services because of the importance of such feedback in the improvement of the organizational operations since reciprocity is the building block of business relationships. In addition, privacy is very important to customers in their interactions and communications with organizations because customers will feel threatened if their privacy is not protected.

Queensland Rail Association (2014) found that their organizational policy promoted customer feedback in term of their products, services and business operations because of its role in improving their service delivery. Furthermore, gathered feedback from organizational customers will not be disclosed or used except for the purpose of improving the service or the product's quality. Additionally, the Taxi Service Commission (2013) indicated that the customer had the right to complain about any dissatisfactory service or product. In addition, all information collected for the purpose of addressing a customer's feedback should be handled with full privacy and according to the information privacy act of the organization, and the details and the results of a customer's feedback should not be communicated to other parties. Furthermore, seeking customer feedback means that the organization is customer-oriented and this will enhance customer satisfaction and strengthen the customer organization relationship and prolong its duration. Thus, the following hypotheses were proposed to be tested in this study:

H2a: There is a statistically-significant effect for privacy on maintaining long-term relationships with customers.

H2b: There is a statistically-significant effect for feedback on mediating the relationship between privacy and maintaining long-term relationships with customers.

\subsection{Feedback and Relationship Longevity}

With regard to feedback, Hattie and Timperley (2007) defined feedback as "information provided by an agent regarding aspects of one's performance or understanding” (pp.81). According to the Communication Handbook (2013) feedback describes the receiver's attitude and response toward the communicated message. Normally, feedback could be in the form of acknowledgment; for example, showing that the customer has heard the supplier's message by parroting or repeating the words of the message and/or paraphrasing it by rephrasing the supplier's message with the customers own words (Team Coordination Training Student Guide, 1998). Furthermore, Lunenburg (2010) argues that improper feedback will hinder the communication rather than improving or adding value to it. Therefore, the following hypotheses were proposed to be tested:

H3a: There is a statistically-significant effect for feedback on maintaining long-term relationships with customers.

H3b: Feedback will mediate the relationship between the marketing ethics elements and maintaining long-term relationships with consumers.

\subsection{Honesty and Relationship Longevity}

Kanagal (2009) found that good and effective relations in the hotels sector contained elements of honesty and transparency in business communications and interactions. The communication in business interactions is crucial in the business relationship building process and the maintenance of the relationship (Grönroos, 2004).

A Merck/MSD Company (2011) concluded that the organizational success was highly-influenced by honest communication between the organization's employees and their customers. In addition to this, the quality of the shared information is highly-appreciated if treated with honesty, without invasion of customer privacy and transparency. As a result, a successful organization encourages open communication that is characterized by encouraging customers to give feedback.

McKimm et al. (2007) indicated that gathering customer feedback requires organizational employees having interpersonal skills to achieve open business communication benefits. Furthermore, feedback should be generated from 
customers regularly to sustain the quality of the business relationship. In addition, honest and clear feedback reduces hidden or unclear areas between the organization's employee and the customer.

Hacker et al. (1999) indicated that a crucial element in the trust-building process between the organization and the customer is the feedback provided regarding the interacting party's performance and expectations in an honest and clear manner. This contributes to the establishment of a productive business relationship. Thus, the hypotheses to test includes:

H4a: There is a statistically-significant effect for honesty on maintaining long-term relationships with customers

H4b: There is a statistically-significant effect for feedback on mediating the relationship between honesty and maintaining long-term relationships with customers.

\subsection{Transparency and Relationship Longevity}

The Ken Blanchard Companies (2010) indicated that both business and personal information require trust to be established, and, as a result, open, honest and transparent feedback is crucial in business transactions to develop long-term relationships with customers. The International Bank for Reconstruction and Development (2012) concluded that achieving effective business required business activities to be transparent, and this necessitated access to the customer's information to increase the transparency in the business transaction environment. In addition, sharing customers' feedback with decision makers is important as this feedback might manipulate the decision maker's way of thinking and management to ensure customer satisfaction. KPMG International for advisory service (2013) indicated that feedback-seeking practices were a form of seeking continuous improvement to an organization's service or product and thus achieving higher levels of customer satisfaction, retention and, thus, a stronger organization-customer relationship, because feedback serves as an opportunity. Consequently, the hypotheses to be tested will be:

H5a: There is a statistically-significant effect for transparency on maintaining long-term relationships with customers.

H5b: There is a statistically-significant effect for feedback on mediating the relationship between transparency and maintaining long-term relationships with customers.

\section{The Study Model}

Based on previous literature that explains the study main dimensions in more details and highlights the suggested relationships among the study constructs, figure 4.1 demonstrate the proposed directions clearly.

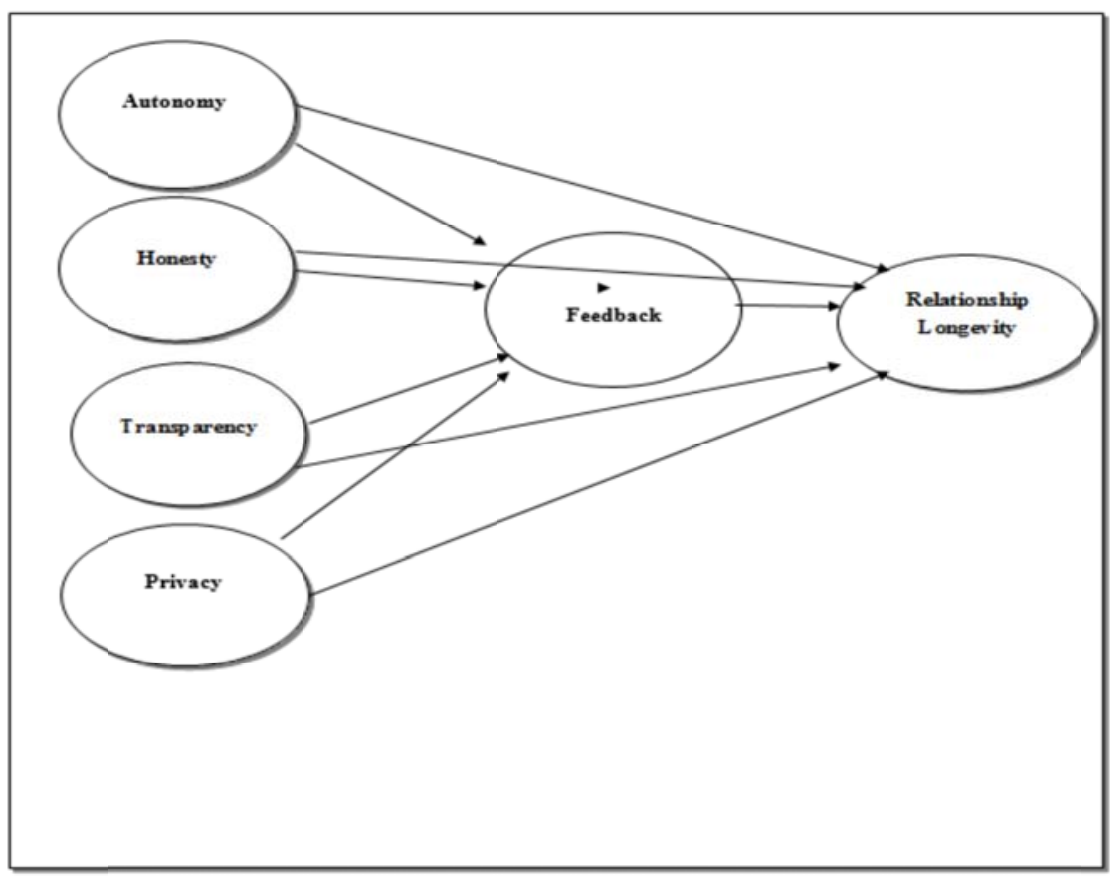

Figure 1. The Study Model

\section{Research Methodology}

To achieve the objectives of this study and test the casual relationships between the variables of this study, a quantitative research design was employed with the primary data collected through questionnaires (Saunders et al, 2011). Furthermore, owing to the large size of the target population, this study adopted a random sampling method. Therefore, a 
representative sample size that reflected the population of the study was calculated to be 400 (Sakran \& Bougi, 2009). As recommended by Sekran, (2003), a pilot study was conducted, first, to ensure that the questions were clear and understandable to participants. Ten participants with a marketing background were interviewed and given a copy of the questionnaire asking them to make suggestions regarding any issue they might encounter to enhance the quality of the questionnaire. The purpose of the pilot study was to ensure the linguistic quality and the collection procedures effectiveness. However, the participants did not report any issues regarding the questionnaires. Subsequently, 400 questionnaires were disseminated by hand to the participants, namely, mobile phone subscribers, while 360 questionnaires were retrieved, giving a response rate of $90 \%$ as explained in appendix table 2.

Moreover, as seen in Table 3.1, all the scales used in the study were reliable and had acceptable levels of internal consistency. Appendix table 1 gives a full list of all study constructs' items that used in collecting the primary data.

Table 3-1. Reliability statistics

\begin{tabular}{ccc}
\hline Scale item & Cronbach's alpha value & No of item \\
\hline Honesty & $75.2 \%$ & 5 \\
Autonomy & $73.4 \%$ & 9 \\
Privacy & $80.9 \%$ & 5 \\
Transparency & $73.4 \%$ & 5 \\
Relationship Marketing & $76.5 \%$ & 10 \\
Feedback & $73.5 \%$ & 5 \\
All items & $91.3 \%$ & 39 \\
\hline
\end{tabular}

Regarding the demographic characteristics of the sample, $67.8 \%$ of the study sample are females and $31.9 \%$ are males as seen in the appendix table 3 . Also, $87.8 \%$ of the sample were less than 23 years old, which might be related to the study sample itself being constituted from the youth category as shown in the appendix table 4 . Considering the fact that most of the promotional activities sponsored by telecommunication sector aim at the youth, the target sample age was justified. Additionally, since the majority of the sample was less than 23 years old, $96.7 \%$ of the sample participants were single as shown in the appendix table 5 . Regarding the sample's educational level, $85.5 \%$ held a bachelor degree as shown in the appendix table 6. Finally, the majority of the sample's income level was low, with 50.3\% earning less than the 300 J.D income level as shown in the appendix table 7. With regard to the sample distribution and the participants' subscription duration, as seen in Appendix 8, the highest percentages of the study participants were Zain subscribers with 78.9\% followed by Umniah subscribers with $15.6 \%$ and only $5.6 \%$ for Orange subscribers. This was not surprising considering that Zain has the biggest market share in Jordan with $39.18 \%$ of the whole cellular market share, followed by Orange 31.21\%, then Umniah 28.96\% (TRC, 2014). Additionally, as seen in Appendix 8, the highest percentage of the participants' subscription duration was from one to three years with $40.3 \%$, followed by four to six years with $33.3 \%$. This meant that $73.6 \%$ of the study's participants had been telecommunication subscribers for a significant duration, and were thus able to analyze the ethical practice of the selected companies and answer the related questions.

To examine the influence of each independent variable on relationship marketing, hierarchical regression analysis was used to test the hypotheses as it allows for determining the contribution for each independent variable (Pallant, 2010). In addition, structural equation modelling was utilized by using Amos software to test for the mediation effects.

\section{Findings}

To test the study model as seen in table $4-1$, all study independent constructs explained $40.6 \%$ of the total variance of the model and the whole model was significant $(p<0.00)$ with no significant influence for the demographic variables.

Table 4-1. Model Summary

\begin{tabular}{cccccc}
\hline Model & $\mathrm{R}$ & $\begin{array}{c}\mathrm{R} \\
\text { Square }\end{array}$ & $\begin{array}{c}\text { Adjusted R } \\
\text { Square }\end{array}$ & $\begin{array}{c}\text { Std. Error of } \\
\text { the Estimate }\end{array}$ & $\begin{array}{c}\text { Sig. F } \\
\text { Change }\end{array}$ \\
\hline 1 & $.637^{\mathrm{a}}$ & .406 & .397 & .41775 & .000 \\
\hline
\end{tabular}

Moreover, the findings of the regression tests supported H2a, H3a, H4a and H5a. However, H1a was rejected since no significant influence was found for autonomy on maintaining long-term relationships with customers. These findings are also supported by the findings of Aztiria et al. (2008), Lunenburg (2010), McKimm et al. (2007), Kanagal (2009) as well as Wirtz and Lwin (2009) who found that these ethical dimensions and elements had an influence.

To test the effect of study constructs' effects on maintaining customer-supplier relationships , the path tests has been employed to test the relationship between feedback, honesty, privacy, transparency, autonomy and relationship marketing was statistically-significant for the effects of privacy, honesty, transparency and feedback on relationship marketing. On the other hand, the path between autonomy and relationship marketing was statistically-insignificant. Feedback had the higher beta value (beta=31.8, $p<.001$ ) which indicated the individual contribution of each predictor (variable) to the model (Pallant, 2010), followed by transparency (beta=.23.4, $p<.001$ ), privacy (beta=-.18.1, $p<.05$ ), and honesty (beta $=.11 .5, p<.05$ ). 
Furthermore, to test for the relationship between the marketing ethics elements and relationship marketing with feedback as a mediator, the bootstrapping approach was conducted using Amos owing to its higher statistical power compared to the multiple regression analysis techniques in addition to producing direct and indirect effects (Obeidat, 2014; Mallinckrodt, Abraham, Wei \& Russell, 2006). As suggested by Hair et al (2010), 2000 bootstrap samples with 95\% confidence intervals were requested. Afterwards, the test for the relationship between the marketing ethics components with and without the mediator was run. As seen in the Table (4-2), the beta value for the path between the marketing ethics elements and relationship marketing is shown in the first column. Table (4-2) also shows the direct and indirect effects after the mediator is introduced in the second and third columns. Furthermore, for a full mediation effect, the direct effect becomes non-significant once the mediator is introduced with the indirect effect significant (Hair et al, 2010). For an indirect mediation both effects should be insignificant with the indirect effect significant (Obeidat, 2014). However, as seen in Table (4-2), all the paths were significant which suggested a partial mediation for feedback between the marketing ethics elements and relationship marketing. Thus, H1b, H2b, H3b, H4b and H5b were all supported.

Table 4-2. Mediation analysis results

\begin{tabular}{ccccc}
\hline Path & $\begin{array}{c}\text { Direct without } \\
\text { feedback }\end{array}$ & $\begin{array}{c}\text { Direct with } \\
\text { feedback }\end{array}$ & $\begin{array}{c}\text { Indirect with } \\
\text { feedback }\end{array}$ & $\begin{array}{c}\text { Mediation } \\
\text { type }\end{array}$ \\
\hline Honesty to relationship marketing & $.29^{* * *}$ & $36.8^{* *}$ & $.16 .4^{* *}$ & Partial \\
Privacy to relationship marketing & $.29 .5^{* * *}$ & $.29 .2^{* *}$ & $.14 .2^{* *}$ & Partial \\
Autonomy to relationship marketing & $.30^{* * *}$ & $.22^{* *}$ & $.14 .5^{* *}$ & Partial \\
Transparency to relationship marketing & $.44^{* * *}$ & $.33 .5^{* *}$ & $.16 .6^{* *}$ & Partial \\
\hline
\end{tabular}

Additionally, to examine the application of the main marketing ethics elements among the subscribers of the three main telecommunications firms in Jordan, a one-way analysis of variance was conducted to compare the participants' perceptions of the marketing ethics dimensions among the three firms (Pallant, 2010). The participants were divided into three main groups according to the firm to which they were subscribed (group 1: Zain, group 2: Umniah, group 3: Orange). Interestingly, there was a statistically-significant difference between the three groups for only one marketing ethics dimension, that is, honesty, $\mathrm{F}(2,357)=4.3, \mathrm{P}<.05$. The effect size calculated through the beta squared was $(.02)$. Moreover, the mean score for Zain was $(\mathrm{M}=3.26, \mathrm{SD}=.6844),(\mathrm{M}=2.97, \mathrm{SD}=.6499)$ for Umniah, and $(\mathrm{M}=3.25$, $\mathrm{SD}=.789$ ) for Orange. This result means that the perceptions of the main ethical dimensions were perceived similarly between all three groups except for the "honesty" element which was perceived as higher for Zain subscribers.

\section{Conclusion}

Organizations these days are losing their valid customers at a notable rate. For example, mobile phone service providers in the UK market lose over a third of their mobile phone subscribers to rival providers yearly (Andic, 2006). As a result, organizations adopt a variety of marketing approaches to create and maintain relationships with their customers. Corporate social responsibility has also emerged as an integrated management practice acceptable from customers and even many times encouraged by the governments. Precisely, corporate social responsibility refers to applying moral management and a set of ethical standards in organizational strategic and action plans (Robin \& Reidenbach, 1987; Carroll, 1991). It has also been highlighted by many scholars such as Creyer (1997) that marketing ethics is seen as a method to generate customer interest and affect their decisions to buy organizations' products and/or services. Thus, to prolong customer-supplier relationship, there is a need to apply the basic business ethics standards that seem to be efficient in reducing customer risk, reducing both transaction conflict and cost, reducing switching costs and efforts, increasing transactional benefits, increasing customer satisfaction, trust, commitment and loyalty (Bejou et al., 1998, Valenzuela et al., 2010; Alshurideh, 2014a; Alshurideh, 2014b; Alshurideh et al., 2015; Alshurideh, 2016a; Alshurideh, 2016b).

Thus, this research has made an attempt to examine the influence of a set of marketing ethics elements on maintaining long-term relationships with consumers in the telecommunication sector in Jordan. A sample of 360 participants was used to examine this relationship on the basis of identified elements, namely, honesty, privacy, transparency and autonomy. It was found that except for the element of 'honesty', there was no difference between the ethical orientations of the questionnaires participants who subscribed to different telecommunication companies, thus suggesting that all three firms generally employed the elements of marketing ethics. Considering statistical outputs, one of the four identified elements, namely, 'autonomy' was found to be playing the weaker role in comparison to rest of the three elements in maintaining long-term relationships with customers This study also examined the role of 'feedback' as a mediator between the marketing ethics elements and relationship marketing and found that feedback partially mediated the relationship between all the marketing ethics elements and relationship marketing. Consequently, this finding demonstrates the importance of effective communication between a firm and its customers. As a result, the high competitively in the telecommunications sector between these firms has encouraged them to adopt ethical and social guidelines. In addition, to differentiate their product offerings these firms have all developed good customer service 
mechanisms to better communicate their offerings and handle complaints. Therefore, it comes as no surprise that feedback was an important mediator in the findings of this study. For the organizations, it is also suggested to not only incorporate ethical elements in their practices but also promote these practices in the media, especially their websites. They should analyze their webpage contents enabling customers to conveniently provide their feedback (Vij, 2014). Overall, the research has added an important value to the marketing ethics literature by showing the effect of marketing ethics elements in a new context selected, the telecommunication sector in Jordan, which remains one of the most competitive business sectors in Jordan.

However, like any other social research, this study is limited by the design and methodology used. Nonetheless, the results form a basis for future research that can be conducted in a new context. It is suggested that future research is conducted to investigate the difference between different industries in terms of employing ethical practices and feedback generation. In addition, a case study approach could also be used to examine more closely the application of the different elements of marketing ethics. Moreover, future research could also examine the application of ethics elements on cross-cultural bases, which would allow for new insights on the nature of marketing ethics elements. Finally, it is hoped that this study will generate an awareness among business sectors, about the importance of applying various elements of marketing ethics.

\section{References}

Abela, A. V., \& Murphy, P. E. (2008). Marketing with integrity: ethics and the service-dominant logic for marketing. Journal of the Academy of Marketing Science, 36(1), 39-53. http://dx.doi.org/10.1007/s11747-007-0062-0

Adcock, D., Al, H., \& Ross, C. (2001). Introduction. Marketing: principles and practice 4th ed. 15. Retrieved 2009-10-23.

Alshurideh, M. (2014a). A Qualitative Analysis of Customer Repeat Purchase Behaviour in the UK Mobile Phone Market. Journal of Management Research, 6(1), 109-125. http://dx.doi.org/10.5296/jmr.v6i1.4659

Alshurideh, M. (2014b). The Factors Predicting Students' Satisfaction with Universities’ Healthcare Clinics' Services: A Case-Study from the Hashemite Kingdom of Jordan. Dirasat, Administrative Science, 2(41), 451-464. http://dx.doi.org/10.12816/0007482

Alshurideh, M. (2016). Is Customer Retention Beneficial for Customers: A Conceptual Background. Journal of Research in Marketing, 5(3), 382-389. http://dx.doi.org/10.17722/jorm.v5i3.126

Alshurideh, M. (2016). Scope of Customer Retention Problem in the Mobile Phone Sector: A Theoretical Perspective. Journal of Marketing and Consumer Research, 20, 64-69.

Alshurideh, M., Bataineh, A., Alkurdi, B., \& Alasmr, N. (2015). Factors affect Mobile Phone Brand Choices - Studying the Case of Jordan Universities Students. International Business Research, 8(3), 141-155. http://dx.doi.org/10.5539/ibr.v8n3p141

American Nurses Association. (2011). Short Definitions of Ethical Principles and Theories Familiar words, what do they mean? Ethical principles-American Nurses Association Description, 1-2.

Andic, S. (2006). Mobile operators must tune into youth market. New Media Age, 11(9), 7.

Aztiria, A., Augusto, J., \& Izaguirre, A. (2008). Autonomous Learning of User’s Preferences improved through User Feedback. BMI, 72-86.

Bejou, D., Christine, T. E., \& Adrian, P. (1998). Trust, ethics and relationship satisfaction. International Journal of Bank Marketing, 16(4), 170-175. http://dx.doi.org/10.1108/02652329810220729

Bollen, A., \& Emes, C. (2008). Understanding Customer Relationship, How Important is the Personal Torch. Ipsos MORI, 5-46.

Business dictionary. (2014). Feedback Definitions.

Buttle, F. (1996). Relationship marketing, theory and practice, Sage Publications, London. http://dx.doi.org/10.4135/9781446252062

Canadian Marketing Association. (2004). Incorporating Privacy into Marketing and Customer Relationship Management, a Joint Report of the Information and Privacy Commissioner of Ontario and the Canadian Marketing Association, 1-20. Available online at: https://www.ipc.on.ca/images/Resources/priv-mkt.pdf

Carroll, A. B. (1991). The pyramid of corporate social responsibility: Toward the moral management of organizational stakeholders. Business horizons, 34(4), 39-48. http://dx.doi.org/10.1016/0007-6813(91)90005-G

Cateora, P., Gilly, M., \& Graham, J. (2009). International Marketing, $14^{\text {th }}$ edition, McGraw-Hill Education, New York. 
Chonko, L. B., \& Hunt, S. D. (1985). Ethics and marketing management: An empirical examination. Journal of Business Research, 13(4), 339-359. http://dx.doi.org/10.1016/0148-2963(85)90006-2

Communication Handbook. (2013). Communication definitions.

Cramton, P., \& Dees, J. (1993). Promoting honesty in negotiation: an exercise in practical ethics, Business Ethics Quarterly, 3(4), 359-394. http://dx.doi.org/10.2307/3857284

Creyer, E. H. (1997). The influence of firm behavior on purchase intention: do consumers really care about business ethics. Journal of consumer Marketing, 14(6), 421-432. http://dx.doi.org/10.1108/07363769710185999

Eagle, L. (2009). Social marketing ethics. London: National Social Marketing Centre. Available online at: http://eprints.uwe.ac.uk/54/1/NSMC_Ethics_Report.pdf

Fan, Y. (2005). Ethical branding and corporate reputation. Corporate communications: An international journal, 10(4), 341-350. http://dx.doi.org/10.1108/13563280510630133

Ferrell, O. C. (2007). Nature and scope of marketing ethics. In G. Gundlach, L. Block \& W. Wilkie (Eds), Explorations of marketing in society, 858-952.

Ferrell, O., Gresham, L., \& Fraedrich, J. (1989). A synthesis of ethical decision maker. Journal of Macro marketing, 55-63. http://dx.doi.org/10.1177/027614678900900207

Grönroos, C. (2004). The relationship marketing process: communication, interaction, dialogue, value. Journal of business \& industrial marketing, 19(2), 99-113. http://dx.doi.org/10.1108/08858620410523981

Hacker, S., Israel, J., \& Couturier, L. (1999). Building trust in key customer- supplier relationships. The performance center and satisfaction strategies, 1-10. Available online at: http://www.satisfactionstrategies.com/paper4.pdf

Hair, J. F., Black, W. C., Babin, B. J., \& Anderson, R. E. (2010). Multivariate data Analysis, 7th edition, Upper Saddle River, New Jersey: Pearson.

Hassan, A., Chachi, A., \& AbdulLatiff, S. (2008). Islamic marketing ethics and its impact on customer satisfaction in the Islamic banking industry. Islamic Economics, 21(1). Available online at: https://www.kau.edu.sa/Files/320/Researches/51086_21220.pdf http://dx.doi.org/10.4197/islec.21-1.2

Hattie, J., \& Timperley, H. (2007). The Power of Feedback. Review of Educational Research, 77(1), 81-112. http://dx.doi.org/10.3102/003465430298487

Hawkins, D. E. (2011). The Importance of Relationships: Evaluating the dynamics and challenges of relationships in business. London: Palgrave Macmillan.

Hunt, S. D., Chonko, L. B., \& Wilcox, J. B. (1984). Ethical problems of marketing researchers. Journal of Marketing Research, 309-324. http://dx.doi.org/10.2307/3151607

Hunt, S., \& Parraga, A. (1993). Organizational Consequences, Marketing Ethics, and Sales force Supervision, Journal of Marketing Research, 78-90.

Jamnik, A. (2011). Business ethics in financial sector. Ekonomska istraživanja, 24(4), 151-161. http://dx.doi.org/10.1080/1331677x.2011.11517489

Kanagal, N. (2009). Role of relationship marketing in competitive marketing strategy. Journal of Management and Marketing Research, 2(1), 1-17. Available online at: http://www.jid.aabri.com/manuscripts/09204.pdf

Khalili, A., Wu, C., \& Aghajan, H. (2009). Autonomous Learning of User’s Preference of Music and Light Services in Smart Home Applications. Behavior monitoring and interpretation workshop at German Al Conference, 1-12.

KPMG International for Advisory Service. (2013). Transparency Report. Available online at: www.kpmg.com

Lanier, C., \& Saini, A. (2008). Understanding Consumer Privacy: A Review and Future Directions, Academy of Marketing Science Review, 12(2): 1-32.

Lunenburg, F. C. (2010). Communication: The Process, Barriers, And Improving Effectiveness, Schooling, 1(1), 1-11.

Majtán, S., \& Dubcová, G. (2008). The Ethics in the Product Marketing, output of the research projects VEGA No. 1/4579/07 Diagnostic of Value Relations and Market Activities in an Enterprise and No. 1/3828/06 "NGOs Integral Part of Economic System of the Country, Projects registered with the Grant Agency in the Slovak Republic, 1-9.

Mallinckrodt, B., Abraham, W. T., Wei, M., \& Russell, D. W. (2006). Advances in testing the statistical significance of mediation effects. Journal of Counseling Psychology, 53(3), 372-378. 
McKimm, J., Jollie, C., \& Hatter, M. (2007). Mentoring: Theory and practice. London Deanery Faculty Development: London.

Merck/MSD. (2011). Our values and standards the basis of our success. Code of Conduct, $3^{\text {rd }}$ Ed, 4-35.

Obeidat, Z. M. I. (2014). Beware the Fury of the Digital Age Consumer: Online Consumer Revenge: A Cognitive Appraisal Perspective, Durham theses, Durham University. Available at Durham E-Theses Online: http://etheses.dur.ac.uk/10808/

Orgerson, J. L., \& Schroeder, J. E. (2005). Identity in marketing communications: an ethics of visual representation working paper. Available online at: http://ssrn.com/abstract=969079

Pallant, J. (2010). SPSS survival manual: A step by step guide to data analysis using SPSS. 4th edition, McGraw-Hill International.

Palmatier, R. W., Scheer, L. K., Evans, K. R., \& Arnold, T. J. (2008). Achieving relationship marketing effectiveness in business-to-business exchanges. Journal of the academy of marketing science, 30, 174-190. http://dx.doi.org/10.1007/s11747-007-0078-5

Palmer, A. (2002). The Evolution of an Idea: An Environmental Explanation of Relationship Marketing. Journal of relationship marketing, 1(1), 79-94. http://dx.doi.org/10.1300/J366v01n01_06

Polonsky, M., Schuppisser, D. S., \& Beldona, S. (2002). A Stakeholder Perspective for Analyzing Marketing Relationships. Journal of Market-Focused Management, 5, 109-126. http://dx.doi.org/10.1023/A:1014091926179

Queensland rail association (2014). Customer feedback information. Available online at: www.queenslandrail.com.au/customerservice.

Robin, D. P., \& Reidenbach, R. E. (1987). Social responsibility, ethics, and marketing strategy: closing the gap between concept and application. The Journal of Marketing, 44-58. http://dx.doi.org/10.2307/1251143

Saunders, M. N., Saunders, M., Lewis, P., \& Thornhill, A. (2011). Research methods for business students, $5^{\text {th }}$ edition. Pearson Education India.

Sekaran, U. (2003). Research Methods for Business: A Skill Building Approach, $4^{\text {th }}$ edition, New York: John Wiley and Sons.

Sekaran, U., \& Bougie, R. (2009). Research methods for business, $5^{\text {th }}$ edition, Chichester, UK: John Willey \& Sons Ltd.

Sheth, J., \& Parvatiyar, A. (2002). Evolving Relationship Marketing into a Discipline. Journal of relationship marketing, 1(1), 3-16. http://dx.doi.org/10.1300/J366v01n01_02

Takala, T., \& Uusitalo, O. (1996). An alternative view of relationship marketing: a framework for ethical analysis. European Journal of marketing, 30(2), 45-60. http://dx.doi.org/10.1108/03090569610106644

Taxi service commission. (2013). A guide to customer feedback and complaints handling, 3-11.

Team Coordination Training Student Guide. (1998). United States department of homeland security, 7, 1-12.

The American communication company Avaya. (2013). The Autonomous Customer 2013 report, 5-12. Available online at: https://www.avaya.com/usa/documents/the_autonomous_customer_survey_2013.pdf

The International Bank for Reconstruction and Development. (2012). Doing business in a more transparent world, $1-61$.

The Ken Blanchard Companies. (2010). Building Trust. Available online at: www.kenblanchard.com

Valenzuela, L. M., Mulki, J. P., \& Jaramillo, J. F. (2010). Impact of customer orientation, inducements and ethics on loyalty to the firm: Customers' perspective. Journal of Business Ethics, 93(2), 277-291. http://dx.doi.org/10.1007/s10551-009-0220-z

Vij, A. (2014). Managing competitive advantage in the cluttered content environment, Proc. of the Intl. Conf. on Advances in Economics, Management and Social Study - EMS 2014. Avaiable online at http://seekdl.org/nm.php?id=3934

Warren, S., \& Brandeis, L. (1890). The right to privacy. Harvard law review, 4(5). 193-220. http://dx.doi.org/10.2307/1321160

Williams, O., \& Murphy, P. (1990). The ethics of virtue: a moral theory for marketing”, Journal of Macro marketing, 10, 19-29. http://dx.doi.org/10.1177/027614679001000103

Winer, R. S. (2001). Customer relationship management: a framework, research directions, and the future, Haas School 
of Business. Available online at: http://groups.haas.berkeley.edu/fcsuit/PDF-papers/CRM\%20paper.pdf

Wirtz, J., \& Lwin, M. (2009). Regulatory Focus Theory, Trust, and Privacy Concern. Journal of Service Research, 12(2), 190-206.

Zwick, D., \& Dholakia, N. (1999). Models of Privacy in the Digital Age: Implications for Marketing and E-Commerce, Research institution for telecommunication and information marketing, 1-2. Available online at: http://ritim.cba.uri.edu/Working\%20Papers/Privacy-Models-Paper[1].pdf 


\section{Appendix}

Table 1. Scale of Measuring the Study Items

\begin{tabular}{|c|c|c|}
\hline Code & Construct & Sources \\
\hline $\mathrm{H}$ & Honesty & Brashear, Boles \\
\hline H1 & My mobile phone supplier is honest. & Bellenger \\
\hline $\mathrm{H} 2$ & My mobile phone supplier usually keeps his promises. & Brooks (2003) \\
\hline H3 & My mobile phone supplier advices on my sales activitie & \\
\hline
\end{tabular}

H4 My confidence in my mobile phone supplier is relatively high, even when he gives me a rather unlikely explanation.

H5 My confidence in my mobile phone supplier is highly related to his honesty.

\section{A Autonomy}

A1 My purchase decisions represent my own values and feelings, without interruption by any mean from my mobile phone supplier.

A2 My purchase activities are strongly identified by myself, without interference by any mean from my mobile phone supplier.

A3 My actions are conformed to who I am and not influenced by my mobile phone supplier.

A4 My whole self stands behind the important purchase decisions I make and not my mobile phone supplier.

A5 My purchase decisions are steadily informed by things I want or care about and without intervention from my mobile phone supplier.

A6 My purchase activities have significant autonomy and are not affected by my mobile phone supplier activities.

A7 My purchasing activity is usually decided based on my own choices and preferences not my mobile phone supplier interests.

A8 My purchases are usually selected with considerable opportunity for independence and freedom, away from pressures.

A9 My mobile phone supplier allows me to use personal initiative or judgment in carrying out my purchasing activity.

\begin{tabular}{lll}
\hline P & Privacy
\end{tabular}

P1 My preferences information that is collected by my mobile phone supplier is considered sensitive to me.

P2 My information that is collected anonymously by my mobile phone supplier is important to me.

P3 My personal information that is collected by my mobile phone supplier is important to me and I am concerned about how to be used.

P4 My personally identifiable information that is collected by my mobile phone supplier is important to me and I am concerned about how the firm will use it.

P5 My personal privacy is important to me while dealing with my mobile phone supplier.

\section{T Transparency}

T1 My mobile phone supplier exchange relevant and beneficial information with me on a regular basis which is important to me

T2 My mobile phone supplier's technical abilities and capabilities are known to me.

T3 My mobile phone supplier's business practices appear to be transparent.

T4 My knowledge about the purpose for which the mobile phone supplier wants to collect information is important to

T5 My knowledge about the way that my mobile phone supplier is going to use my information is important to me.

\section{RM Relationship Marketing}

RM1 My relationship with my mobile phone supplier is expected to continue for a long time.

RM2 My relationship with my mobile phone supplier is planned to be renewed automatically.

RM3 My planned business for the next few years will not be conducted with my mobile phone supplier.

RM4 My business orientation is continually looking out for another mobile phone supplier to replace my supplier.

RM5 My business transactions require a close relationship between me and my mobile phone supplier to ensure its success.

RM6 My close relationship with my mobile phone supplier is important to my success.

RM7 My strong relationship with my mobile phone supplier would be very helpful in buying his products.

RM8 My strong relationship with my mobile phone supplier is needed to buy his products successfully.

RM9 My relationship with my mobile phone supplier is important to me and I work hard to strengthen it.

RM10 My relationship with my mobile phone supplier is important to me and I focus my attention on building and maintaining it.

\section{F $\quad$ Feedback}

F1 My satisfaction by dealing with this mobile phone supplier is highly related to the feedback exchanged with him.

F2 My mobile phone supplier feedback activities significantly affect the level of customer satisfaction.

F3 My mobile phone supplier provides timely feedback about my progress in specific issues while interacting with him.

F4 My mobile phone supplier often provides useful feedback that helps to identify potential problems and opportunities.

F5 My satisfaction is positively related to the feedback provided by my mobile phone supplier.

Barry and Terry (2008)

Palmatier,

Scheer, Evans

and Arnold (2008)

\section{Cheistine (2011)}

Hanover research center (2010)

Chaudoir,

Stephenie, Dugan, Alicia. And Barr, Colin. (2013)

Table 2. Questionnaire Response Rate

\begin{tabular}{cccc}
\hline Questionnaire sent & Questionnaire returned & Questionnaire accepted for analysis & Response Rate \\
\hline 400 & 360 & 360 & $90 \%$ \\
\hline
\end{tabular}


Table 3. Gender

\begin{tabular}{cccc}
\hline Category & Frequency & Percentage \% & Valid Percent \% \\
\hline Male & 115 & $31.9 \%$ & $32.0 \%$ \\
Female & 244 & $67.8 \%$ & $68.0 \%$ \\
Total & 359 & $99.7 \%$ & $100.0 \%$ \\
Missing & 1 & $.3 \%$ & \\
Total & 360 & 100.0 & \\
\hline
\end{tabular}

Table 4. Age (years)

\begin{tabular}{cccc}
\hline Category & Frequency & Percentage \% & Valid Percent \% \\
\hline less than 23 & 316 & $87.8 \%$ & $88.0 \%$ \\
23-less than 29 & 38 & $10.6 \%$ & $10.6 \%$ \\
29-less than 35 & 3 & $0.8 \%$ & $0.8 \%$ \\
more than 35 years & 2 & $0.6 \%$ & $0.6 \%$ \\
Total & 359 & $99.7 \%$ & $100.0 \%$ \\
Missing & 1 & $0.3 \%$ & \\
Total & 360 & $100 \%$ &
\end{tabular}

Table 5. Marital Status

\begin{tabular}{cccc}
\hline Category & Frequency & Percentage $\%$ & Valid Percent\% \\
\hline Single & 347 & $96.4 \%$ & $96.7 \%$ \\
Married & 11 & $3.1 \%$ & $3.1 \%$ \\
Divorced & 1 & $0.3 \%$ & $0.3 \%$ \\
Widowed & 0 & $0 \%$ & $0 \%$ \\
Total & 359 & $99.7 \%$ & $100.0 \%$ \\
Missing & 1 & $0.3 \%$ & \\
Total & 360 & $100 \%$ & \\
\hline
\end{tabular}

Table 6. Educational Level

\begin{tabular}{cccc}
\hline Category & Frequency & Percentage $\%$ & Valid Percent\% \\
\hline Diploma & 30 & $8.3 \%$ & $8.6 \%$ \\
Bachelor & 309 & $85.8 \%$ & $88.8 \%$ \\
Masters & 6 & $1.7 \%$ & $1.7 \%$ \\
PhD & 3 & $0.8 \%$ & $0.9 \%$ \\
Total & 348 & $96.7 \%$ & $100.0 \%$ \\
Missing & 12 & $3.3 \%$ & \\
Total & 360 & $100 \%$ & \\
\hline
\end{tabular}

Table 7. Monthly Income Level

\begin{tabular}{cccc}
\hline Category & Frequency & Percentage $\%$ & Valid Percent \% \\
\hline less than 300jd & 181 & $50.3 \%$ & $53.4 \%$ \\
300-less than 500jd & 59 & $16.4 \%$ & $17.4 \%$ \\
500-less than 700jd & 30 & $8.3 \%$ & $8.8 \%$ \\
700-less than 900jd & 30 & $8.3 \%$ & $3.5 \%$ \\
900-less than 1100jd & 12 & $3.3 \%$ & $8.0 \%$ \\
more than 1100jd & 27 & $7.5 \%$ & $100.0 \%$ \\
Total & 339 & $94.2 \%$ & \\
Missing & 21 & 5.85 & $100.0 \%$ \\
Total & 360 & & \\
\hline
\end{tabular}

Table 8. Cellular Companies Providers

\begin{tabular}{ccc}
\hline Category & Frequency & Percentage\% \\
\hline Zain & 284 & $78.9 \%$ \\
Orange & 20 & $5.6 \%$ \\
Umniah & 56 & $15.6 \%$ \\
Total & 360 & $100.0 \%$ \\
\hline
\end{tabular}

\section{Copyrights}

Copyright for this article is retained by the author(s), with first publication rights granted to the journal.

This is an open-access article distributed under the terms and conditions of the Creative Commons Attribution license (http://creativecommons.org/licenses/by/4.0/). 